\title{
Designed Amino Acid ATRP Initiators for the Synthesis of Biohybrid Materials
}

\author{
Rebecca M. Broyer, Grace M. Quaker, and Heather D. Maynard* \\ Department of Chemistry and Biochemistry and the California NanoSystems Institute, \\ University of California, 607 Charles E. Young Drive East, Los Angeles, CA 90096-1569 \\ maynard@chem.ucla.edu
}

Supporting Information 


\section{Experimental}

\section{Materials.}

All chemicals were purchased from either Acros or Sigma-Aldrich and used as received unless otherwise indicated. Deuterated solvents were purchased from Cambridge Isotope Laboratories. Amino acids, $N, N, N^{\prime} N^{\prime}$-tetramethyl-O-(1H-benzotriazol-1-yl)uronium hexafluorophosphate (HBTU), and H-Gly-2-Chlorotrityl resin were purchased from Novabiochem. 1-Hydroxybenzotriazole (HOBT) was purchased from AnaSpec Incorporated. Styrene and HEMA were passed through a basic alumina column before use. Copper bromide and copper chloride were purified by stirring in glacial acetic acid for $12 \mathrm{~h}$, filtering to collect the solids, rinsing with ethanol and diethyl ether, and drying under high vacuum. Silica gel for column chromatography was purchased from Sorbent Technologies (200-400 mesh). Synthesis of $N$ - $\alpha$-Fmoc-L-tyrosine tert-butyl ester (2) and $N$ - $\alpha$-Fmoc-L-serine-tert-butyl ester (9) proceeded according to literature procedures. ${ }^{1}$ The $\beta$-O-linked $\mathrm{N}$-acetylglucosamine (O-GlcNAc) glycomonomer was synthesized as previously reported. $^{2}$

\section{Analytical Techniques.}

All operations were carried out under a dry argon atmosphere. Gel permeation chromatography (GPC) was conducted on a Shimadzu LC-10ATvp pump equipped with a refractive index detector (RID-10A) and two PLgel mixed-D columns (Polymer Laboratories LTD, $300 \mathrm{~mm}, 5 \mu \mathrm{m}$ ) with a guard column. HPLC grade THF (for polystyrene) or $N, N$-dimethylformamide (DMF) with $0.1 \mathrm{M} \mathrm{LiBr}$ (for glycopolymers and polyHEMA) was used as the eluent (flow rate: $0.8 \mathrm{~mL} / \mathrm{min}$, temperature: $40^{\circ} \mathrm{C}, \mathrm{DMF} ; 23$ 
${ }^{\circ} \mathrm{C}$, THF). Instrument calibration was carried out using near-monodisperse polystyrene standards for the polystyrene samples and poly(methyl methacrylate) standards for the polyHEMA and glycopolymer samples (both standards from Polymer Laboratories). Chromatograms were processed using EZStart 7.2 software. Infrared (IR) spectroscopy was recorded on a Perkin Elmer Spectrum One FT-IR Spectrometer with a Universal ATR Sampling Accessory. Mass spectrometry was performed on an IonSpec Ultima 7T FTICR spectrometer at the UCLA Molecular Instrumentation Center or by the University of by the California Riverside Mass Spectrometry Facility. Analytical and preparatory reverse phase HPLC were carried out on a Shimadzu HPLC system equipped with a UV detector using Alltech Prevail C18 columns (analytical: $5 \mu \mathrm{m}, 150 \times 4.6 \mathrm{~mm}$, flow rate 1 $\mathrm{mL} / \mathrm{min}$; preparatory: $5 \mu \mathrm{m}, 150 \times 22 \mathrm{~mm}$, flow rate $23 \mathrm{~mL} / \mathrm{min}$ ) with monitoring at $\lambda=$ $280 \mathrm{~nm}$ and $220 \mathrm{~nm}$. UV-Vis spectra were recorded on a ThermoSpectronic Biomate 5 Spectrometer. Centrifugation was carried out using an Eppendorf Centrifuge $5702 .{ }^{1} \mathrm{H}$ and ${ }^{13} \mathrm{C}$ NMR spectra were acquired on a Bruker ARX $500 \mathrm{MHz}$, an Avance DRX 500 $\mathrm{MHz}$ or a Bruker Avance $600 \mathrm{MHz}$ spectrometer. Fluorescence was detected using a Photon Technologies International Fluorimeter equipped with a Hammatsu R928 photomultiplier tube (PMT) and excited at $340 \mathrm{~nm}$ with a $75 \mathrm{~W}$ Xe lamp. Peptide synthesis was conducted using the FastMoc 0.25CondMonPrevPk program on an Applied Biosystems 433A Peptide Synthesizer.

\section{Synthetic Procedures}

Synthesis of Fmoc-4-trifluoromethanesulfonyloxy-phenylalanine-OtBu (3). A

solution of 2 (460 mg, $1 \mathrm{mmol})$ and pyridine $(201 \mu \mathrm{L}, 2.5 \mathrm{mmol})$ in methylene chloride 
(1.5 mL) was cooled to $0{ }^{\circ} \mathrm{C}$. Trifluoromethanesulfonic anhydride $(252 \mu \mathrm{L}, 1.5 \mathrm{mmol})$ was added drop wise and the resulting yellow solution was stirred at $0{ }^{\circ} \mathrm{C}$ for $30 \mathrm{~min}$. The reaction mixture was then diluted with water and methylene chloride and the layers were separated. The organic layer was washed with water, $0.5 \mathrm{M} \mathrm{NaOH}$ solution, $10 \%$ citric acid solution, water, then dried over $\mathrm{MgSO}_{4}$ and concentrated. The crude material was purified by silica gel column chromatography (hexane/ethyl acetate, $3 / 1$ ) to give $\mathbf{3}$ in $64 \%$ yield $(379 \mathrm{mg}) .{ }^{1} \mathrm{H}$ NMR (500 MHz, $\left.\mathrm{CDCl}_{3}\right): \delta 7.78(\mathrm{~d}, J=7.5 \mathrm{~Hz}, 2 \mathrm{H}), 7.58(\mathrm{~d}, J$ $=7.5 \mathrm{~Hz}, 2 \mathrm{H}), 7.41(\mathrm{t}, J=7.3 \mathrm{~Hz}, 2 \mathrm{H}), 7.32(\mathrm{t}, J=7.4 \mathrm{~Hz}, 2 \mathrm{H}), 7.19(\mathrm{q}, J=9.1,8.7 \mathrm{~Hz}$, $4 \mathrm{H}), 5.35(\mathrm{~d}, 1 \mathrm{H}), 4.51(\mathrm{~m}, 2 \mathrm{H}), 4.39(\mathrm{~m}, 1 \mathrm{H}), 4.22(\mathrm{t}, J=6.7 \mathrm{~Hz}, 1 \mathrm{H}), 3.10(\mathrm{~d}, J=5 \mathrm{~Hz}$, $2 \mathrm{H}), 1.39(\mathrm{~s}, 9 \mathrm{H}) ;{ }^{13} \mathrm{C}$ NMR $\left(500 \mathrm{MHz}, \mathrm{CDCl}_{3}\right): \delta 170.0,155.4,148.5,143.7,143.6$, 141.3, 141.2, 136.9, 131.2, 127. 7, 127.0, 124.9, 121.1, 119.9, 117.4, 82.8, 66.7, 54.9, 47.1, 37.8, 27.8; IR: 3327, 2981, 1712, 1599, 1500, 1478, 1450, 1420, 1369, 1349, 1286, 1248, 1207, 1179, 1105, 1052, 1033, 1018, $942 \mathrm{~cm}^{-1}$; mass spectrum (FAB) calcd: $592.1617 \mathrm{~m} / \mathrm{z}\left(\mathrm{MH}^{+}\right)$; observed: $592.1631 \mathrm{~m} / \mathrm{z}$.

Synthesis of Fmoc-4-vinyl-phenylalanine-OtBu (4). To a solution of 3 (2.74 g, $4.64 \mathrm{mmol})$ in 1,4-dioxane $(20.8 \mathrm{~mL})$ was added tributyl(vinyl)tin $(1.73 \mathrm{~mL}, 6.0 \mathrm{mmol})$, dry $\mathrm{LiCl}(590 \mathrm{mg}, 13.9 \mathrm{mmol})$, and $\mathrm{Pd}\left(\mathrm{Ph}_{3}\right)_{4}(1.07 \mathrm{~g}, 0.928 \mathrm{mmol})$. The mixture was stirred under argon for $1 \mathrm{~h}$ at room temperature, and then heated at reflux. After $4 \mathrm{~h}$, the reaction flask was cooled and treated with saturated aqueous $\mathrm{KF}$ solution at room temperature for $12 \mathrm{~h}$. The biphasic mixture was diluted with ether, filtered over a pad of Celite, washed with water, $5 \% \mathrm{HCl}$ solution, brine, then dried over $\mathrm{MgSO}_{4}$ and concentrated. The crude oil was purified by silica gel column chromatography (hexane/ethyl acetate, 10/1) to afford 4 in $70 \%$ yield (1.52 g). ${ }^{1} \mathrm{H}$ NMR (500 MHz, 
$\left.\mathrm{CDCl}_{3}\right): \delta 7.80(\mathrm{~d}, J=5 \mathrm{~Hz}, 2 \mathrm{H}), 7.61(\mathrm{t}, J=5 \mathrm{~Hz}, 2 \mathrm{H}), 7.43(\mathrm{t}, J=5 \mathrm{~Hz}, 2 \mathrm{H}), 7.36(\mathrm{~m}$, 4H), $7.16(\mathrm{~d}, J=5 \mathrm{~Hz}, 2 \mathrm{H}), 6.73(\mathrm{dd}, J=5,10 \mathrm{~Hz}, 1 \mathrm{H}), 5.76(\mathrm{~d}, J=15 \mathrm{~Hz}, 1 \mathrm{H}), 5.41$ (d, $J=10 \mathrm{~Hz}, 1 \mathrm{H}), 5.26(\mathrm{~d}, J=10 \mathrm{~Hz}, 1 \mathrm{H}), 4.60(\mathrm{q}, J=5 \mathrm{~Hz}, 1 \mathrm{H}), 4.48(\mathrm{~m}, 1 \mathrm{H}), 4.37(\mathrm{~m}$, $1 \mathrm{H}), 4.24(\mathrm{t}, J=7 \mathrm{~Hz}, 1 \mathrm{H}), 3.14(\mathrm{t}, J=6.8 \mathrm{~Hz}, 2 \mathrm{H}), 1.47(\mathrm{~s}, 9 \mathrm{H}) ;{ }^{13} \mathrm{C} \mathrm{NMR}(500 \mathrm{MHz}$, $\left.\mathrm{CDCl}_{3}\right): \delta 170.5,155.5143 .8,141.2,136.4,136.3,135.7,134.8,129.7,128.1,127.6$, 127.0, 126.2, 125.9, 125.1, 125.0, 119.9, 113.6, 82.4, 66.8, 55.0, 47.1, 38.0, 27.9; IR: $3338,2975,2924,1716,1610,1510,1478,1449,1393,1367,1353,1286,1250,1221$, 1152, 1107, 1053, 1033, $1020 \mathrm{~cm}^{-1}$; mass spectrum (FAB) calcd: $470.2331 \mathrm{~m} / \mathrm{z}\left(\mathrm{MH}^{+}\right)$; observed: $470.2315 \mathrm{~m} / \mathrm{z}$.

Synthesis of Fmoc-4-(1-chloroethyl)-phenylalanine-OH (5). Protected amino acid 4 (200 $\mathrm{mg}, 0.43 \mathrm{mmol})$ was dissolved in methylene chloride $(0.5 \mathrm{~mL})$, and cooled to $0{ }^{\circ} \mathrm{C}$. The mixture was then treated with glacial acetic acid $(0.4 \mathrm{~mL})$ and concentrated $\mathrm{HCl}(0.04 \mathrm{~mL})$ and an additional $0.8 \mathrm{~mL}$ of $\mathrm{HCl}$ was added throughout the course of the reaction. After stirring for $18 \mathrm{~h}$ at room temperature, the mixture was diluted with methylene chloride and water and the layers were separated. The organic layer was washed twice with $2.5 \% \mathrm{NaHCO}_{3}$, water, and brine, and dried over $\mathrm{MgSO}_{4}$. The crude material was purified by silica gel column chromatography (hexane/ethyl acetate, 10/1, with $10 \%$ acetic acid). Remaining acetic acid was azeotroped with hexanes to yield the product 5 in $60 \%$ yield $(116 \mathrm{mg}) .{ }^{1} \mathrm{H}$ NMR $\left(500 \mathrm{MHz}, \mathrm{CDCl}_{3}\right): \delta 7.77(\mathrm{~d}, J=10 \mathrm{~Hz}, 2 \mathrm{H})$, $7.55(\mathrm{t}, 2 \mathrm{H}), 7.36(\mathrm{~m}, 6 \mathrm{H}), 7.13(\mathrm{~d}, J=10 \mathrm{~Hz}, 2 \mathrm{H}), 5.18(\mathrm{~d}, J=9 \mathrm{~Hz}, 1 \mathrm{H}), 5.07(\mathrm{q}, J=$ $8.5 \mathrm{~Hz}, 1 \mathrm{H}), 4.47(\mathrm{~m}, 1 \mathrm{H}), 4.42(\mathrm{~m}, 2 \mathrm{H}), 4.22(\mathrm{t}, 1 \mathrm{H}), 3.17(\mathrm{~m}, 2 \mathrm{H}), 1.81(\mathrm{~d}, J=8 \mathrm{~Hz}$, $3 \mathrm{H}) ;{ }^{13} \mathrm{C}$ NMR $\left(500 \mathrm{MHz}, \mathrm{CDCl}_{3}\right): \delta 177.29,155.79,143.61,141.64,141.23,135.64$, $129.57,127.69,127.01,126.75,125.01,124.94,119.94,67.04,58.34,54.46,47.01$, 
37.21, 26.31; IR: 2925, 1715, 1514, 1449, 1421, 1342, 1228, $1049 \mathrm{~cm}^{-1}$; mass spectrum (FAB) calcd: $450.1472 \mathrm{~m} / z\left(\mathrm{MH}^{+}\right)$; observed: $450.1455 \mathrm{~m} / \mathrm{z}$.

Synthesis of Fmoc-4-(1-chloroethyl)-phenylalanine-glycine methyl ester (6). Amino acid 5 (56 mg, $0.12 \mathrm{mmol})$ and glycine methyl ester hydrochloride $(15.4 \mathrm{mg}, 0.12$ mmol) were dissolved in dry DMF $(0.37 \mathrm{~mL})$ and treated with 2-(1H-9 azobenzotriazole1-yl)-1,1,3,3-tetramethylammonium hexafluorophosphate (HATU; $47 \mathrm{mg}, 0.12 \mathrm{mmol}$ ) followed by $N, N^{\prime}$-diisopropylethylamine (DIPEA, $64 \mu \mathrm{L}, 0.37 \mathrm{mmol}$ ) under argon. After $3 \mathrm{hr}$ at $23{ }^{\circ} \mathrm{C}$, the reaction was diluted with methylene chloride and water, and the layers were separated. The aqueous layer was extracted three times with methylene chloride. The combined organic layers were washed once each with $10 \% \mathrm{HCl}$, water, $2.5 \%$ $\mathrm{NaHCO}_{3}$ and then dried over $\mathrm{MgSO}_{4}$. The crude material was purified by silica gel chromatography (hexane/ethyl acetate, 6/1, with 10\% acetic acid). Remaining acetic acid was azeotroped with hexanes to give the product 6 in $44 \%$ yield $\left(28 \mathrm{mg}\right.$ ). ${ }^{1} \mathrm{H}$ NMR (500 $\left.\mathrm{MHz}, \mathrm{CDCl}_{3}\right): \delta 7.80(\mathrm{~d}, J=5 \mathrm{~Hz}, 2 \mathrm{H}), 7.58(\mathrm{~m}, 2 \mathrm{H}), 7.45(\mathrm{t}, J=7 \mathrm{~Hz}, 2 \mathrm{H}), 7.36(\mathrm{~m}$, 4H), 7.23 (bd, 2H), 6.49 (bs, 1H), 5.25 (bs, 1H), 5.44 (bs, 1H), 5.09 (q, $J=5 \mathrm{~Hz}, 1 \mathrm{H}$ ), $4.47(\mathrm{~m}, 3 \mathrm{H}), 4.21(\mathrm{t}, J=6 \mathrm{~Hz}, 1 \mathrm{H}), 4.02(\mathrm{~m}, 2 \mathrm{H}), 3.76(\mathrm{~s}, 3 \mathrm{H}), 3.15(\mathrm{~m}, 2 \mathrm{H}), 1.84(\mathrm{~d}, J=$ $10 \mathrm{~Hz}, 3 \mathrm{H}) ;{ }^{13} \mathrm{C}$ NMR $\left(500 \mathrm{MHz}, \mathrm{CDCl}_{3}\right): \delta 170.85,169.63,154.73,143.57,141.53$, $141.18,136.24,129.44,127.63,126.96,126.76,124.88,119.88,66.97,58.27,52.27$, 47.00, 41.07, 37.79, 26.26; IR: 3307, 3065, 2927, 2852, 1750, 1661, 1536, 1449, 1211, 1045, 759, $740 \mathrm{~cm}^{-1}$; mass spectrum (FAB) calcd: $521.1843 \mathrm{~m} / \mathrm{z}\left(\mathrm{MH}^{+}\right)$; observed: $521.1855 \mathrm{~m} / \mathrm{z}$.

Typical polymerization of styrene (7). A dry Schlenk tube containing $\mathrm{CuCl}$ (1.9 mg, $0.019 \mathrm{mmol}$ ), 2,2'-bipyridine (bipy; $9 \mathrm{mg}, 0.058 \mathrm{mmol}$ ), and 6 (10 mg, $0.019 \mathrm{mmol}$ ) 
was evacuated and refilled with argon five times. Styrene $(220 \mu \mathrm{L}, 1.9 \mathrm{mmol})$ that had been bubbled with argon for $1 \mathrm{hr}$ was added to the Schlenk tube via an airtight syringe. The tube was placed in a $130{ }^{\circ} \mathrm{C}$ oil bath and sealed. Kinetic samples were removed at timed intervals. Percent conversions were calculated by comparison of the integration of the alkene proton peaks of the styrene monomer $(5.80 \mathrm{ppm}, 5.30 \mathrm{ppm}$; $1 \mathrm{H}$ each) with the integration of the growing polymer peaks $(1.55 \mathrm{ppm} ; 2 \mathrm{H})$. Upon completion of the polymerization, the polymer was dissolved in THF, passed through a neutral alumina column, and precipitated into cold methanol. The polymer was isolated by centrifugation and was precipitated again from THF into methanol. Molecular weight determination by ${ }^{1} \mathrm{H}$ NMR was accomplished by comparing the integration of the Fmoc protons (7.76 ppm; $2 \mathrm{H})$ of the end-group to the polymer peaks $(6.58-6.39 \mathrm{ppm} ; 2 \mathrm{H})$.

Synthesis of Fmoc-O-(2-bromoisobutyryl)-serine tert-butyl ester (10). Ester 9 $(1.57 \mathrm{~g}, 4.1 \mathrm{mmol})$ was added to a solution of 2-bromoisobutyryl bromide $(0.53 \mathrm{~mL}, 4.3$ mmol) and DIPEA $(1.78 \mathrm{~mL}, 10.3 \mathrm{mmol})$ in THF at $0{ }^{\circ} \mathrm{C}$. The solution was allowed to warm to $23{ }^{\circ} \mathrm{C}$ and stirred under argon for $12 \mathrm{~h}$. The reaction mixture was diluted with water $(100 \mathrm{~mL})$ and extracted with $\mathrm{CH}_{2} \mathrm{Cl}_{2}(3 \times 100 \mathrm{~mL})$. The organic layers were combined, dried over $\mathrm{MgSO}_{4}$, filtered, and concentrated under reduced pressure. The crude material was purified by flash silica gel chromatography (hexanes/ethyl acetate, $1 / 1)$ to give $\mathbf{1 0}$ in $66 \%$ yield $(1.28 \mathrm{~g}) .{ }^{1} \mathrm{H}$ NMR $\left(500 \mathrm{MHz}, \mathrm{CDCl}_{3}\right): \delta 7.77(\mathrm{~d}, J=7.6 \mathrm{~Hz}$, $2 \mathrm{H}), 7.60(\mathrm{~d}, J=7.6 \mathrm{~Hz}, 2 \mathrm{H}), 7.40(\mathrm{~m}, 2 \mathrm{H}), 7.31(\mathrm{~m}, 2 \mathrm{H}), 5.60(\mathrm{~d}, J=6.9 \mathrm{~Hz}, 1 \mathrm{H})$, $4.57(\mathrm{~m}, 2 \mathrm{H}), 4.49(\mathrm{~m}, 1 \mathrm{H}), 4.41-4.36(\mathrm{~m}, 2 \mathrm{H}), 4.24(\mathrm{t}, J=7.1 \mathrm{~Hz}, 1 \mathrm{H}), 1.92(\mathrm{~s}, 6 \mathrm{H})$, $1.50(\mathrm{~s}, 9 \mathrm{H}) ;{ }^{13} \mathrm{C} \mathrm{NMR}\left(500 \mathrm{MHz}, \mathrm{CDCl}_{3}\right): \delta 171.3,168.1,156.0,143.8,141.3,127.8$, 127.1, 125.2, 120.0, 83.4, 67.3, 65.7, 55.3, 53.9, 47.1, 30.7, 28.0; IR: 3374, 3015, 2980, 
2930, 2852, 1743, 1724, 1708, 1525, 1449, 1390, 1368, 1309, 1262, 1248, 1229, 1153, 1101, 1091, 1063, 1045, 1019, 1005, 996, 965, $944 \mathrm{~cm}^{-1}$; mass spectrum (ESI-MS) calcd: $554.1154 \mathrm{~m} / z\left(\mathrm{MNa}^{+}\right)$; observed: $554.1153 \mathrm{~m} / z$.

Synthesis of Fmoc-O-(2-bromoisobutyryl)-serine (11). A quantity of $20 \mathrm{ml}$ of $20 \%$ trifluroacetic acid (TFA) in $\mathrm{CH}_{2} \mathrm{Cl}_{2}$ was added to $\mathbf{1 0}(0.76 \mathrm{~g}, 1.4 \mathrm{mmol})$ and the mixture was stirred for $1 \mathrm{~h}$. The solvent was evaporated. The crude material was purified by flash silica gel chromatography (hexanes/ethyl acetate, $4 / 1$, with $10 \%$ acetic acid). Remaining acetic acid was azeotroped with hexanes to afford $\mathbf{1 1}$ in $90 \%$ yield $(0.66 \mathrm{~g})$. ${ }^{1} \mathrm{H}$ NMR $\left(500 \mathrm{MHz}, \mathrm{CDCl}_{3}\right): \delta 7.76(\mathrm{~d}, J=7.4 \mathrm{~Hz}, 2 \mathrm{H}), 7.60(\mathrm{~m}, 2 \mathrm{H}), 7.40(\mathrm{t}, J=7.4$ Hz, 2 H), 7.32 (t, $J=7.4 \mathrm{~Hz}, 2 \mathrm{H}), 5.61(\mathrm{~d}, J=7.5 \mathrm{~Hz}, 1 \mathrm{H}), 4.76(\mathrm{~m}, 1 \mathrm{H}), 4.59(\mathrm{~m}, 2 \mathrm{H})$, $4.43(\mathrm{t}, J=7.3 \mathrm{~Hz}, 2 \mathrm{H}), 4.25(\mathrm{t}, J=6.7 \mathrm{~Hz}, 1 \mathrm{H}), 1.93(\mathrm{~s}, 6 \mathrm{H}) ;{ }^{13} \mathrm{C}$ NMR $(500 \mathrm{MHz}$, $\left.\mathrm{CDCl}_{3}\right): \delta 172.9,171.3,156.0,143.7,141.3,127.79,127.1,125.1,120.0,67.6,64.9$, 55.3, 53.9, 47.0, 30.5; IR: 3430, 3194, 2960, 2926, 2853, 1733, 1714, 1511, 1463, 1449, $1405,1393,1361,1327,1283,1256,1235,1201,1175,1112,1099,1052,1025,1008$, 962, 945, 935 $\mathrm{cm}^{-1}$; mass spectrum (ESI-MS) calcd: $498.0528 \mathrm{~m} / z\left(\mathrm{MNa}^{+}\right)$; observed: $498.0519 \mathrm{~m} / \mathrm{z}$.

Synthesis of VM(11)VVQ(Trt)T(tBu)K(Mca)G. Fmoc-Lys(Mca)-OH (456 mg, $0.78 \mathrm{mmol})$, Fmoc-Thr( $t \mathrm{Bu})-\mathrm{OH}$ (310 mg, $0.78 \mathrm{mmol})$, Fmoc-Gln(Trt)-OH (476 mg, $0.78 \mathrm{mmol}$ ), Fmoc-Val-OH (265 mg, $0.78 \mathrm{mmol}$ ), Fmoc-Val-OH (265 mg, $0.78 \mathrm{mmol}$ ), 11 (371 mg, $0.78 \mathrm{mmol})$, Fmoc-Met-OH (290 mg, $0.78 \mathrm{mmol})$, and Fmoc-Val-OH (265 $\mathrm{mg}, 0.78 \mathrm{mmol}$ ) were sequentially added to H-Gly-2-ClTrt resin (Novasyn, $250 \mathrm{mg}$, $0.195 \mathrm{mmol}$ ) using a peptide synthesizer with HOBT (105 $\mathrm{mg}, 0.78 \mathrm{mmol})$ and HBTU (296 mg, $0.78 \mathrm{mmol}$ ) as coupling agents. The resin was dried under high vacuum for $12 \mathrm{~h}$ 
prior to adding $10 \mathrm{~mL}$ of acetic acid, trifluoroethanol (TFE), and $\mathrm{CH}_{2} \mathrm{Cl}_{2}(2 / 2 / 6)$. The vial was swirled periodically for $2 \mathrm{~h}$. The solution was then filtered to remove the resin, added to an excess of hexanes, and the solvent was removed in vacuo. Remaining acetic acid was azeotroped with hexanes. The crude product was analyzed by analytical HPLC and purified by preparatory HPLC. The following time program was used: A = HPLC grade Acetonitrile, $\mathrm{B}=$ ultrapure water, $0-40 \mathrm{~min}, 30-95 \% \mathrm{~A}$. Collected peak eluted at 24.4 min. Mass spectrum (ESI-MS) calcd: $1610.6856 \mathrm{~m} / \mathrm{z}\left(\mathrm{MH}^{+}\right)$; observed: $1610.7000 \mathrm{~m} / \mathrm{z}$.

Typical polymerization of HEMA. Polymerizations were carried out using standard Schlenk techniques. Initiator 10 (10 mg, $0.018 \mathrm{mmol})$, HEMA (99 $\mu 1,0.9 \mathrm{mmol})$ and $\mathrm{MeOH}(85 \mu \mathrm{l})$ were added to the Schlenk tube. The mixture was degassed using a freeze-pump-thaw cycle (3x). A stock solution of catalyst was prepared by adding $\mathrm{CuBr}$ (21 $\mathrm{mg}, 0.154 \mathrm{mmol}$ ) and bipy ( $45 \mathrm{mg}, 0.288$ ) to a dry 2 neck round bottom flask. The flask was evacuated and refilled with argon five times, and a quantity of $200 \mu$ of degassed $\mathrm{MeOH}$ was added to the solution. A portion $(25 \mu \mathrm{l})$ of the degassed copper catalyst stock solution was then added to start the polymerization, and the mixture was stirred under argon at $23{ }^{\circ} \mathrm{C}$. The reactions were stopped by exposure to oxygen. The polymers were then isolated by precipitation into cold diethyl ether $(4 \mathrm{x})$ followed by drying under vacuum. ${ }^{1} \mathrm{H}$ NMR analysis confirmed that no residual monomer or initiator remained in the final ether layer. Molecular weight determination by ${ }^{1} \mathrm{H}$ NMR was accomplished by comparing the integration of the Fmoc protons peaks (7.34 and 7.26 ppm; $4 \mathrm{H}$ ) of the initiator with the polymer peaks of the side chain methylene protons (3.98 and $3.72 \mathrm{ppm}, 4 \mathrm{H}$ ). In kinetic experiments, the same procedure was employed in methanol- $\mathrm{d}_{4}$ and aliquots were removed periodically and diluted in methanol- $\mathrm{d}_{4}$ for ${ }^{1} \mathrm{H}$ 
NMR analysis. The conversion for polyHEMA was calculated by comparing the integrals of the alkene proton peak of the monomer $(6.07 \mathrm{ppm}, 1 \mathrm{H})$ with those of the overlapping monomer and polymer peaks of the methylene protons next to the ester $(3.96 \mathrm{ppm}, 2 \mathrm{H})$. For each sample, the methanol was evaporated and the residue was dissolved in DMF for GPC analysis.

Polymerization of glycomonomer (12). Polymerizations were carried out using standard Schlenk techniques. Initiator $10(4.8 \mathrm{mg}, 0.009 \mathrm{mmol})$, glycomonomer (150 mg, $0.45 \mathrm{mmol}), \mathrm{MeOH}(400 \mu \mathrm{l})$ and $\mathrm{H}_{2} \mathrm{O}(75 \mu \mathrm{l})$ were added to the Schlenk tube. The solution was degassed using freeze-pump-thaw cycles (3x). A stock solution of catalyst was prepared by adding $\mathrm{CuBr}(11 \mathrm{mg}, 0.077 \mathrm{mmol})$ and bipy $(22.5 \mathrm{mg}, 0.144)$ to a dry 2 neck round bottom flask. The flask was evacuated and refilled with argon five times, and a quantity of $200 \mu \mathrm{l}$ of dry $\mathrm{MeOH}$ was added to the solution. The degassed copper catalyst stock solution $(25 \mu \mathrm{l})$ was then added to start the polymerization, and the mixture was stirred under argon at $23{ }^{\circ} \mathrm{C}$. The reactions were stopped by exposure to oxygen. Polymers were purified using Millipore Amicon 5000 MWCO centrifugation tubes (4x) and isolated by lyophilization. In kinetic experiments, the same procedure was employed in methanol- $\mathrm{d}_{4}: \mathrm{D}_{2} \mathrm{O}$, and aliquots were removed. The conversion for the O-GlcNAc polymer was calculated by comparing the integrals of the alkene proton peaks of the monomer $(6.03 \mathrm{ppm}, 1 \mathrm{H})$ and those of the backbone methyl protons on the glycopolymer (1.10 ppm- $0.50 \mathrm{ppm}, 3 \mathrm{H})$. The solvent was removed and DMF added to the samples for GPC analysis. 


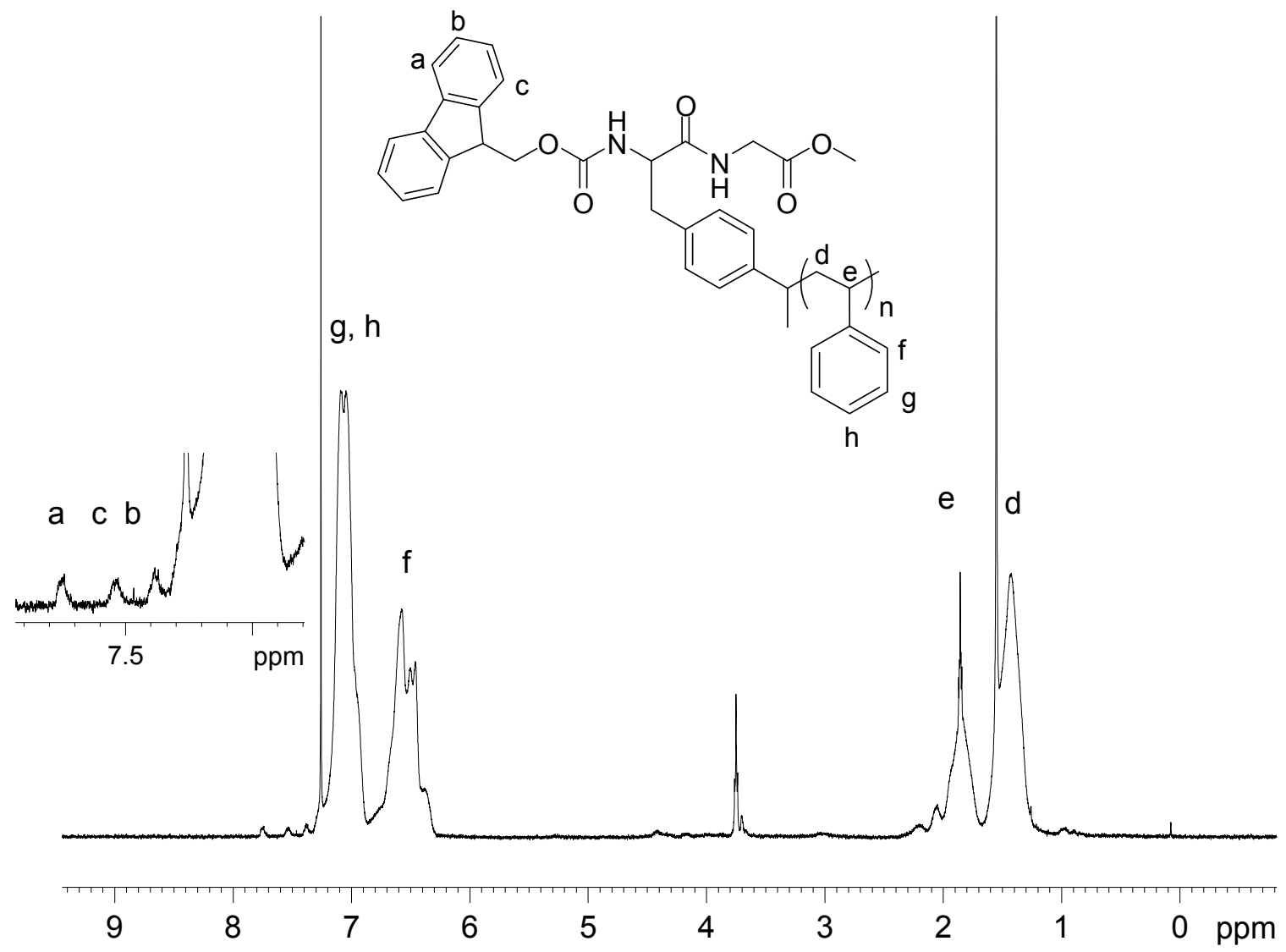

Figure S1. ${ }^{1} \mathrm{H}$ NMR spectrum $\left(600 \mathrm{MHz}, \mathrm{CDCl}_{3}\right)$ of 7. 


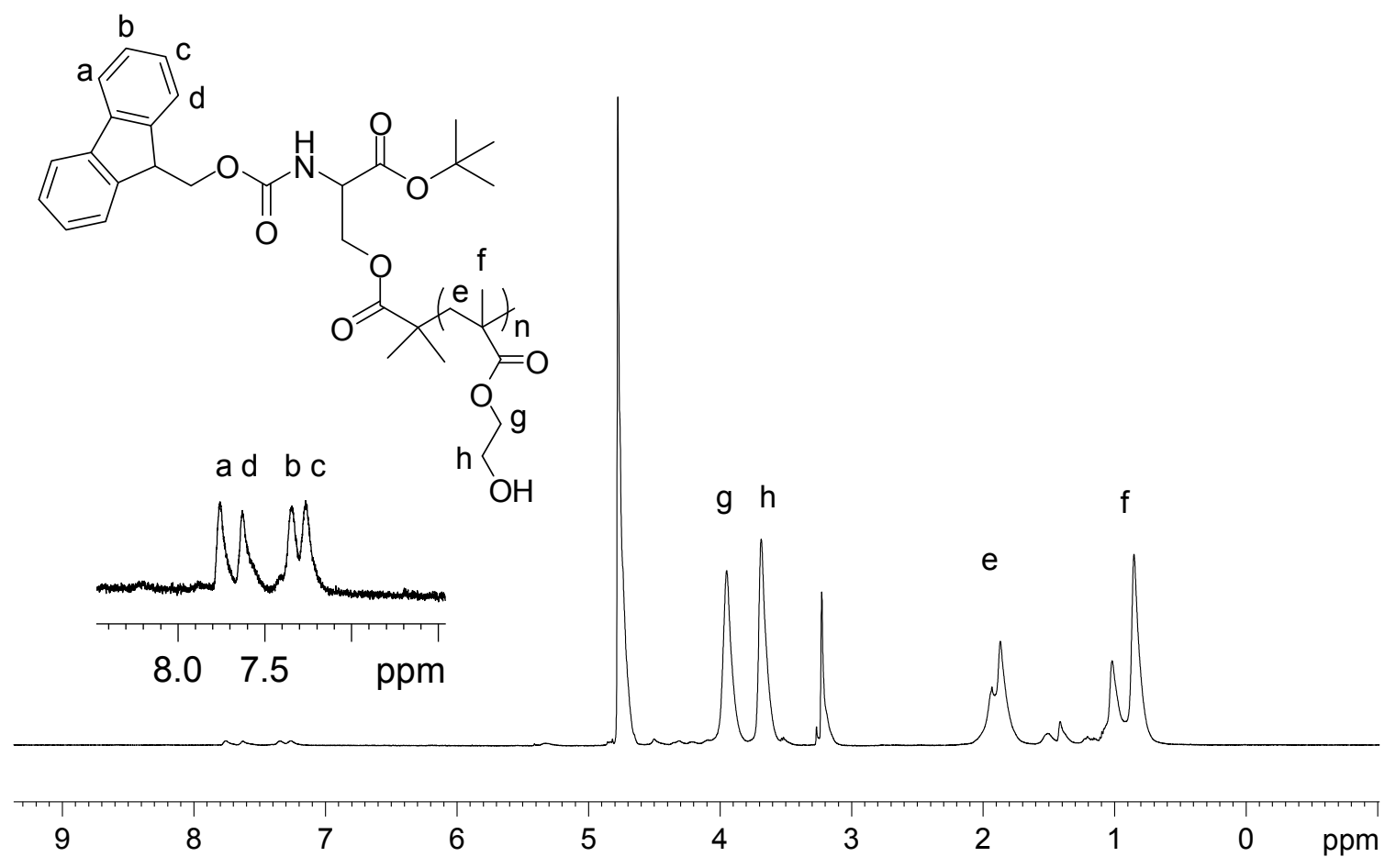

Figure S2. ${ }^{1} \mathrm{H}$ NMR spectrum $\left(500 \mathrm{MHz}\right.$, methanol- $\left.d_{4}\right)$ of polyHEMA ([M]::[I]0 $\left.:[\mathrm{CuBr}]_{0}:[\mathrm{bipy}]_{0}=50: 1: 1: 2\right)$. 




Figure S3. ${ }^{1} \mathrm{H}$ NMR spectrum $\left(500 \mathrm{MHz}, \mathrm{D}_{2} \mathrm{O}\right)$ of glycopolymer 12.

\section{References}

(1) Rothman, D. M.; Vazquez, M. E.; Vogel, E. M.; Imperiali, B. J. Org. Chem. 2003, 68, 6795-6798.

(2) Vázquez-Dorbatt, V.; Maynard, H. D. Biomacromolecules 2006, 7, 2297-2302. 